\title{
INTERPRETATION OF SEDIMENTARY PROCESSES USING ECHO-CHARACTER DISTRIBUTION: CASE STUDY OF PIRAQUÊ-AÇU AND PIRAQUÊ-MIRIM ESTUARINE SYSTEM, ARACRUZ - ES (BRAZIL)
}

\author{
Alex Evaristo da Silva, Pedro Smith Menandro, Kleverson Alencastre do Nascimento, \\ Valéria da S. Quaresma and Alex C. Bastos
}

\begin{abstract}
This research aimed to map distinct types of echo-character in order to recognize estuarine sedimentary processes along the Piraquê-Açu System, in Aracruz, Espírito Santo State, Brazil. Echo-character mapping was undertaken using high frequency sub-bottom profiling data. Four echo-character (EC1, EC2, EC3, EC4) patterns were recognized by combining sub-bottom and surficial sedimentological data. These EC patterns defined three distinct areas within the system that are characterized by the predominance of a specific echo-character and a seabed type: i) estuarine mouth, where sand beds with low penetration prevail; ii) a transition zone, where sandy-muddy and muddy-sandy beds are associated with a high penetration echo-character; and, iii) the rivers/estuary Piraquê-Açu and Piraquê-Mirim with sandy-muddy and muddy beds with high penetration echo pattern. The interpretation showed that the association of EC and surficial sediment may represent modern sedimentary processes within the estuary. Three sedimentary processes were recognized: a) marine dominated processes showing sand transport by tidal currents; b) estuarine processes with fine sediment input, resuspension and deposition; and c) erosive estuarine processes or scour lags, exposing possibly relict deposits.
\end{abstract}

Keywords: estuarine sedimentation, shallow geophysics, sub-bottom profiler.

RESUMO. Esse estudo busca reconhecer os tipos de ecocaráter existentes para o melhor entendimento dos processos sedimentares do sistema estuarino do PiraquêAçu e Piraquê-Mirim, localizado no município de Aracruz, Espírito Santo. 0 reconhecimento e 0 mapeamento dos tipos de ecocaráter foram realizados a partir de registros de perfilador de subfundo de alta frequência. Através da associação dos dados geofísicos com dados sedimentológicos foram reconhecidos e definidos quatro padrões de ecocarácteres (EC1, EC2, EC3, EC4) associados a tipos de fundo distintos. A distribuição espacial dos tipos de eco permitiu a divisão do estuário em três áreas distintas que diferem pela predominância de diferentes tipos de ecocaráter e sedimento: i) A foz do sistema estuarino, interpretada como região de dominância marinha, onde predomina o fundo arenoso e a baixa penetração do sinal; ii) A zona de confluência, onde predomina sedimentos areno-lamosos a lamo-arenosos com penetração do sinal acústico; iii) Os braços Piraquê-Açu e Piraquê-Mirim de predomínio de fundo areno-lamoso a lamoso, com penetração do sinal. Estas áreas estão associadas a distintos processos sedimentares, sendo eles: a) processos marinhos com transporte de sedimentos arenosos por correntes de maré (foz do sistema até a confluência dos braços); b) processos estuarinos com aporte, resuspensão e deposiçãa de sedimentos finos, típicos da região interna do sistema; e c) processos estuarinos erosivos ou de ravinamento, ocorrendo localmente nos braços.

Palavras-chave: sedimentação estuarina, geofísica rasa, perfilador de subfundo.

Universidade Federal do Espírito Santo, Departamento de Oceanografia e Ecologia, Av. Fernando Ferrari, 514, Campus Goiabeiras, 29060-900 Vitória, ES, Brazil. Phone: +55(27) 3335-2878 - E-mails: alexevaristos@gmail.com; pedromenandro@hotmail.com; kleversonalencastre@gmail.com; valeria.quaresma@ufes.br; alex.bastos@ufes.br; ac.bastos@terra.com.br 


\section{INTRODUCTION}

Studies involving sedimentary and morphological characterization of the seabed (Flood, 1980; Cooke et al., 2007; Veronez Júnior et al., 2009a) are important not only to scientific purposes but also to support the planning of various human activities such as construction of coastal/marine structures, mapping of mineral deposits, identification of marine habitats, definition of navigation channels, and others. Studies about the acoustic response from echo-characters (EC) are a widely applied tool to recognize sedimentary facies and sedimentary processes. This technique can be applied not only to map the seabed, but also to infer the hydrodynamic and sedimentary processes acting in the environment (Laine et al., 1986; Quaresma et al., 2001; Belo et al., 2002; Catanzaro et al., 2004; García-García et al., 2004; Palomino et al., 2009).

Each type of identified echo-character is associated with a different type of seabed and/or sub-bottom (Souza, 2006), responding differently to sedimentary parameters such as particle size, layer thickness, porosity, compaction, and density, among others.

Damuth (1975) was the first author to associate echocharacter types with sedimentary processes, and although this author studied deep regions, several others applied this principle to shallow marine/coastal areas (Quaresma et al., 2001; Nitsche et al., 2004; Veronez Júnior et al., 2009b). It is noteworthy that when analyzing echo-characters in shallow waters, the geomorphological and hydrodynamic factors of the area should be considered in order to accomplish a more accurate interpretation (Palomino et al., 2009).

Thus, this study aims to associate high-resolution subbottom profiler echo-character with surface sediment distribution in order to recognize patterns of dominant sedimentary processes existing in an estuarine system.

The Piraquê-Açu and Piraquê-Mirim Estuarine System (PAPMES) is located in Aracruz, Espírito Santo State (Fig. 1). The PAPMES crosses an area classified as sector 3 by Martin et al. (1996), where narrow coastal plains are located adjacently to the tablelands of the Barreiras Formation. It is a typical Y-shaped estuary, of drowned valley, formed during the last post glacial marine transgression. The proximity of the Barreiras Formation to the main channel imposes special conditions for sediment distribution, morphology and extent of mangroves (Silva et al., 2013). This system is of great scientific interest, since it is typically the first transgressive feature south of a prograding coast represented by the Rio Doce Delta, and has been the subject of various geoenvironmental studies since 2010. The system is subjected to a micro-tidal regime.
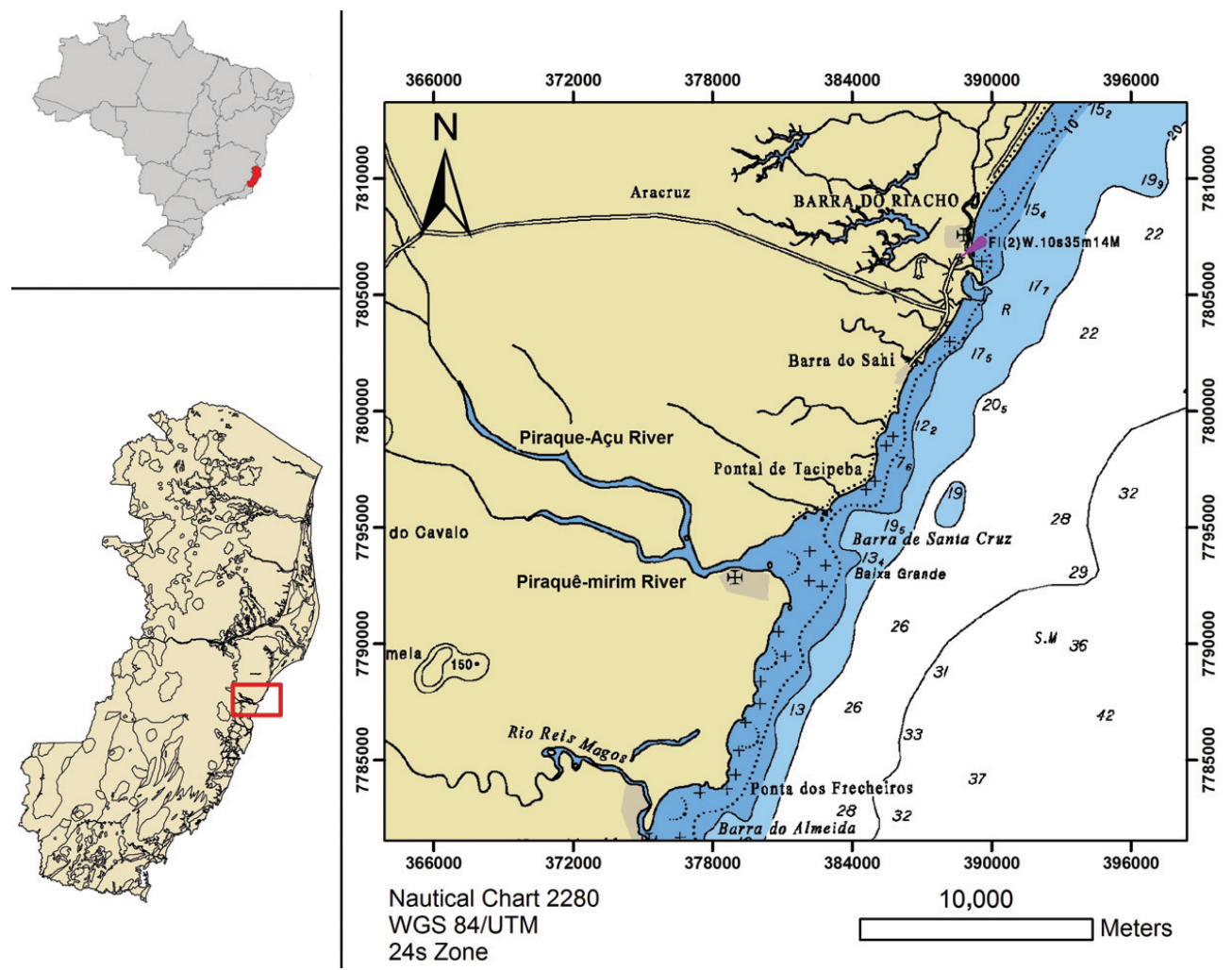

Figure 1 - Study area location. 


\section{METHODOLOGY}

The research consists of correlating acoustic data with textural properties of bottom sediments.

The geophysical surveys were carried out along the estuary using a high frequency $(10 \mathrm{kHz})$ Stratabox sub-bottom profiler. A total of $42 \mathrm{~km}$ of seismic lines were collected. The data was processed and interpreted using SonarWizMap-5 software, from Chesapeake Technology. The echo-characters were determined by:

i) considering the degree of penetration and reflection;

ii) occurrence of sub-bottom reflectors and

iii) geometry of the reflectors (occurrence of hyperboles).

A total of 90 surface samples were collected (Fig. 2) and analyzed to determine the distribution pattern of the surface sediment. Grain size distribution was determined by dry sieving analysis at 1/2 phi intervals. Qualitative and direct correlation between echocharacters, mean grain size and sand/mud ratio were performed.

Data was overlapped and grouped seeking to relate directly the backscatter signal and the properties of the seabed sediment, recognizing patterns of distribution and variability of sediments and depositional processes.

\section{RESULTS AND DISCUSSION}

\section{Sedimentology}

The distribution of the mean sediment grain size along the estuary (Fig. 3) showed a change from medium to coarse sand near the mouth and the head of the estuary, ranging from fine to very fine sands up to the bifurcation of the system. Sandy sediments (coarse and medium) predominate near the mouth and the head of the Piraquê-Açu, areas of higher energy due to both tidal and river currents. The intermediate portion of the Piraquê-Açu branch has predominantly muddy-sand sediments (mud associated with fine and very fine sand), suggesting a zone of lower energy, in which marine and fluvial processes are counterbalanced. This distribution corresponds to the classical model of estuarine facies proposed by Dalrymple et al. (1992).

On the other hand, the Piraquê-Mirim branch displayed different deposition patterns, with predominance of medium and coarse sands after a muddy area at the riverhead. This sandy characteristic is possibly associated with a higher current flow as a function of the local geomorphology (lower width between the river banks) (Silva et al., 2013). The coarse and medium sand sediments observed in the upstream portion of the Piraquê-Açu River suggest greater fluvial influence, because they are outside

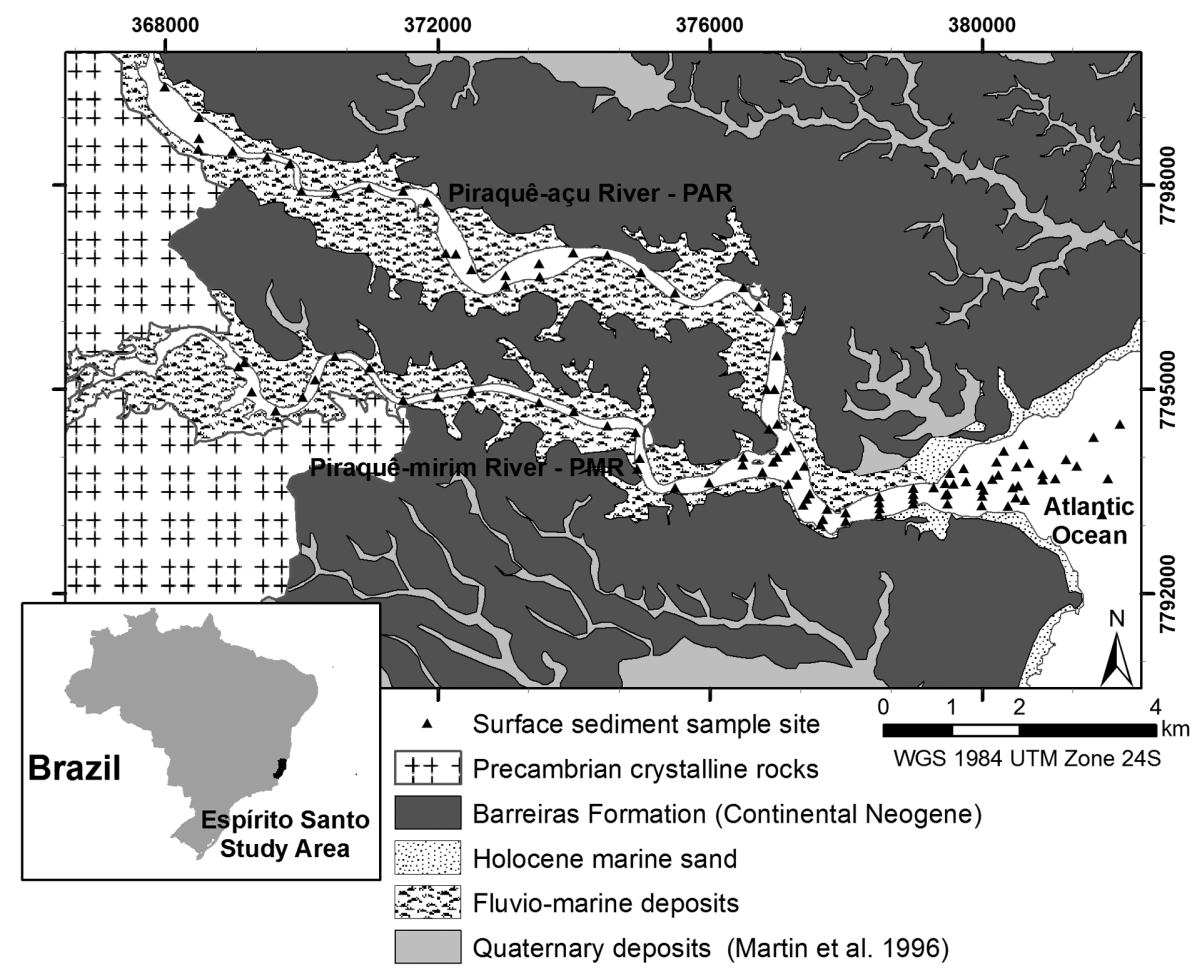

Figure 2 - Geomorphological map of the study area showing the surface sediment sampling locations (modified from Silva et al., 2013). 
the areas where sediment is reworked by waves and tides, while mud deposits in the estuary appear to be associated with stretches where the channel depth is greater. However, there is a sandy stretch (medium sand) that requires further investigation for an appropriate environmental interpretation.

The sedimentary pattern, which is predominantly sandy near the mouth, suggests the influence of tidal forcing. The distribution of mean size grain (Silva et al., 2013) (Fig. 3) shows that, in general, the inner estuary has extensive coverage of fine sediments, which contributed to a good penetration of the acoustic signal since it has low penetration in sand beds.

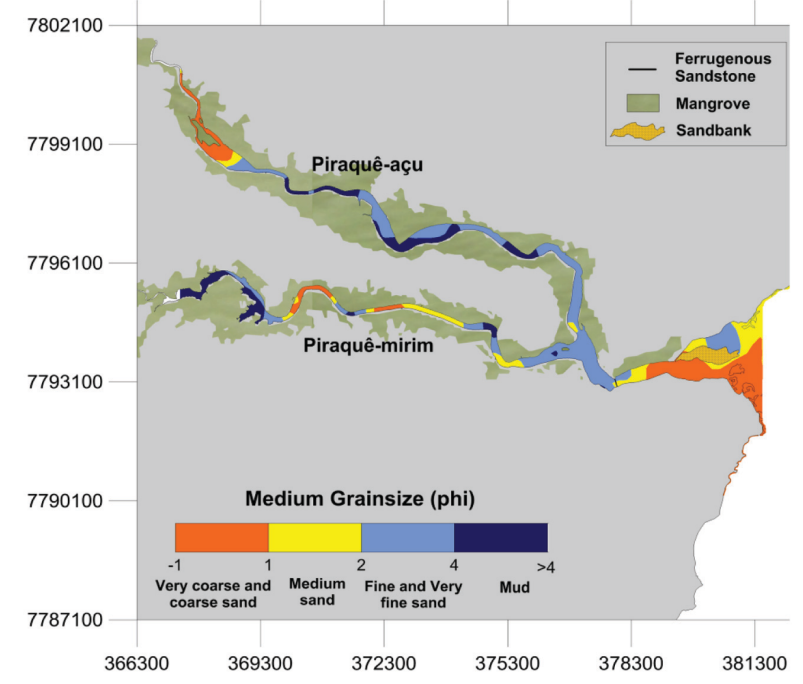

Figure 3 - Mean sediment grain size distribution (after Silva et al., 2013).

\section{Sub-bottom profile}

Four echo-characters (EC) were recognized using the sub-bottom profiler data (Fig. 4):

- Echo-character type 1 (EC1) is characterized by the high reflectivity of the bottom surface and the low penetration of the acoustic signal. It is possible, sometimes, to observe the presence of bed forms.

- Echo-character type 2 (EC2) was distinguished by the low penetration pattern, which enabled to identify the subsurface reflectors and acoustic basement near the bottom.

- Echo-character type 3 (EC3) presented a high reflectivity surface, with high penetration of the acoustic signal. It is possible to observe the plane or irregular acoustic basement, and also diffuse acoustic expressions which have been interpreted as the presence of gas in the sediment, similar to the acoustic turbidity observed by Garcia-Gil et al. (1999).
- Echo-character type 4 (EC4) is characterized by high penetration and limited by high reflectivity subsurface reflectors, with irregular/hyperbolic geometry, which indicate the basement.

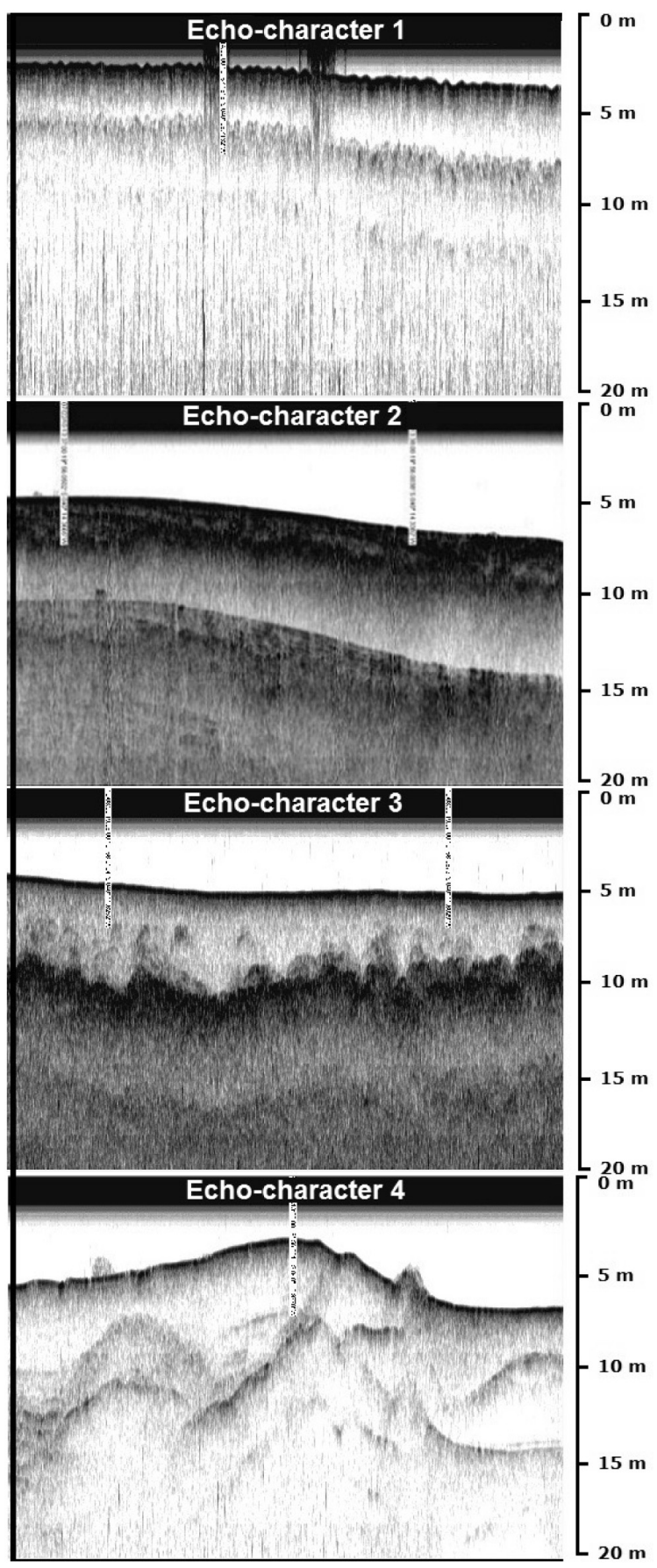

Figure 4 - Different types of echo-character identified in the PAPMES. EC1 high reflection and low penetration; EC2 - low penetration and acoustic basement near the bottom; EC3 - high reflectivity and penetration; EC4 - high penetration and irregular/hyperbolic geometry. 


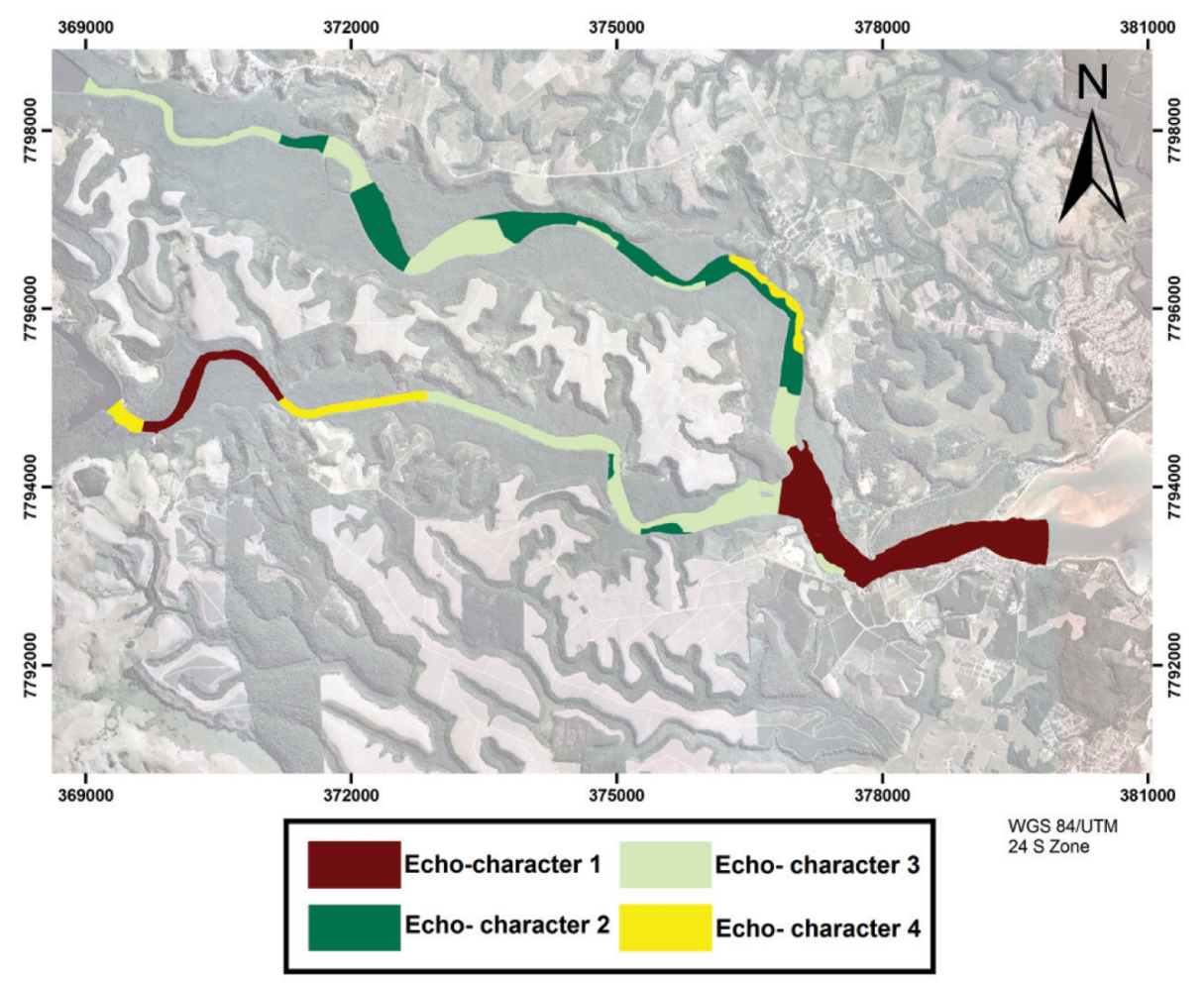

Figure $\mathbf{5}$ - Distribution of different echo-character patterns along the estuarine system.

The spatial distribution of echo-character types (Fig. 5) shows a pattern of low penetration near the mouth of the estuary; with the highest signal penetrations where the fine material is most concentrated, i.e., the inner portion of the estuary. This analysis showed distinct patterns associated with Piraquê-Acu and Piraquê-Mirim branches. In the Piraquê-Mirim branch, near the confluence EC3, and upstream, the echo-characters EC4 and EC1 predominate, where signal penetration is defined by the geomorphology and grain size, respectively.

EC2 prevails in almost all the Piraquê-Açu River extension, except near the confluence where EC3 appears. The EC2 record is interrupted locally; where the occurrence of deposits from the Barreiras Formation along the banks allows the emergence of EC4. EC1 predominates from the confluence of the branches up to the mouth of the estuarine system, associated with a sandy bottom and higher energy sedimentary processes influenced mostly by the sea.

These observations showed that EC1 is associated with higher energy sedimentary processes while EC2 and EC3 types prevail especially in areas classified by Silva et al. (2013) as estuarine domain. The difference lies in the fact that the EC3 type occurs where the sediment distribution is dominated by mud beds. Finally, EC4 type always appears in areas nearby Pre-
Cambrian coastal massifs (according to the geomorphology shown on the map of Fig. 2), which may explain the presence of hyperbolic reflectors.

\section{Recent sedimentary processes}

A sedimentary processes map is shown in Figure 6. This was produced by combining the distribution of mean particle size and echo-character types in the estuary. In addition to the echocharacters and particle size distribution, the compartmentalization of areas (fluvial, marine and estuarine) proposed by Silva et al. (2013) and the analysis of hydrodynamic circulation of this estuarine system (Neves, 2010; Melado, 2011) were also taken into account to produce the map. Table 1 shows a summary of the associations observed in this study.

Figure 6 shows that near the mouth, toward the confluence, the associated processes are mostly marine, according to the low estuary definition by Dalrymple et al. (1992). This interpretation was supported by the fact that sand beds predominate in this portion of echo-character type 1 (low penetration and the possible presence of bottom shapes). Another indication is the high current speeds found in this stretch of the estuary (up to $1.75 \mathrm{~m} / \mathrm{s}$ ), primarily associated with ebb tide currents (Melado, 2011). Franco et al. (2011) mapped subaqueous dunes in this stretch of 


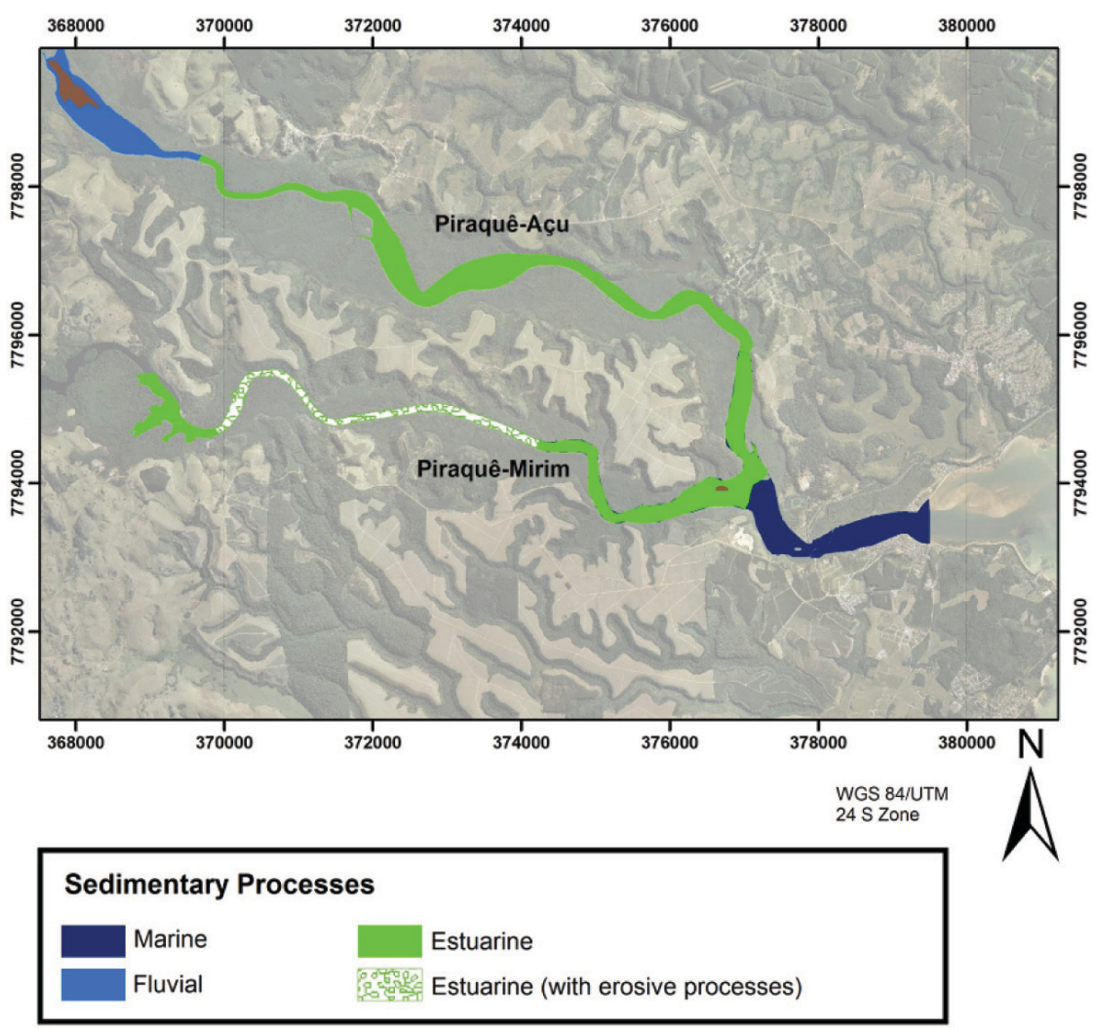

Figure 6 - Modern sedimentary processes along the PAPMES.

the estuary, which are bed forms associated with currents. Thus, this sector of the estuary was interpreted as an area of modern sedimentary processes related to tidal currents.

In the central portion of the Piraquê-Mirim branch, there is a stretch where interpretation shows the occurrence of bottom erosion, exposing relict sediments. The sand sediments may be related to regressive fluvial sands. This part of the estuary presents more intense current speeds than the northern branch $(0.75 \mathrm{~m} / \mathrm{s})$, with hydrodynamic characteristics closer to the mouth of the estuary (Neves, 2010). These current speeds found in this sector of the estuary can be explained by the narrowing of the PiraquêMirim canal banks. This pattern is consistent with the data already presented, and allows, therefore, to classify this area as estuarine dominance with erosive sedimentary processes. It is noteworthy that a similar pattern - predominantly muddy estuarine sedimentation with eroded areas with sandy bottom - was reported by Veronez Júnior et al. (2009b) in the estuarine system of Vitória Bay, further north from the PAPMES.

In the northern part of the estuarine system, the tidal flat appears more developed, which allows storage of large amounts of water in the inter-tidal period. In addition, the current speeds are lower. Thus, recent sedimentary processes were interpreted as a low energy estuarine dominance.

The occurrence of different echo-character types (EC2 and EC3, respectively) in areas classified as of estuarine dominance in Piraquê-Acu and Piraquê-Mirim indicates that particle size is not the only property influencing the response of the acoustic signal. Although the sedimentary distribution of the northern branch shows finer sediments than that of the southern branch, echo-character EC2 is characterized by a lower penetration than that observed in echo-character EC3. Thus, other sediment properties - such as density, porosity and compaction - are possibly influencing the sub-bottom profile data. Other studies have pointed out that the grain size is not the only property that defines the echo type (Belo et al., 2002).

Fluvial dominated sedimentary process was observed at the head of the Piraquê-Acu branch. As the sub-bottom survey did not cover this stretch, this interpretation was based on the occurrence of sandy beds in this area, indicating a higher energy fluvial action, which approaches the characterization of an estuarine head as proposed by Dalrymple et al. (1992). Furthermore, the salinity distribution in this local of the system (Leite et al., 2011) presents low values, limnetic zone, typical of areas with little tidal influence. 
Table 1 - Characteristics of the echo-characters types observed in the PAPMES.

\begin{tabular}{|c|c|c|c|c|c|}
\hline Echo & Description & Sediment & $\begin{array}{l}\text { Associated } \\
\text { processes }\end{array}$ & $\begin{array}{c}\text { Location } \\
\text { occurrence }\end{array}$ & Sub-bottom profile \\
\hline EC1 & $\begin{array}{l}\text { Surface reflector with } \\
\text { high reflectivity, low } \\
\text { penetration, } \\
\text { with/without bed } \\
\text { forms }\end{array}$ & Sand & $\begin{array}{c}\text { Sea } \\
\text { dominance - } \\
\text { tidal currents }\end{array}$ & $\begin{array}{l}\text { Mouth of the } \\
\text { estuary }\end{array}$ & 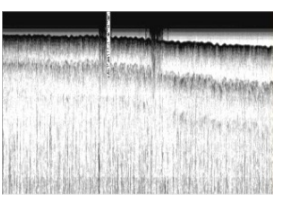 \\
\hline EC2 & $\begin{array}{c}\text { Pattern with the } \\
\text { presence of } \\
\text { subsurface reflectors } \\
\text { with high reflectivity } \\
\text { and acoustic } \\
\text { basement near the } \\
\text { bottom }\end{array}$ & $\begin{array}{l}\text { Sandy- } \\
\text { Mud/Muddy- } \\
\text { sand }\end{array}$ & $\begin{array}{l}\text { Estuarine } \\
\text { dominance }\end{array}$ & $\begin{array}{l}\text { Predominates } \\
\text { along the } \\
\text { Piraquê-Acu }\end{array}$ & \\
\hline EC3 & $\begin{array}{l}\text { Surface reflector with } \\
\text { high reflectivity, } \\
\text { internal reflectors } \\
\text { and/or diffuse gas } \\
\text { structures, with } \\
\text { flat/irregular highly } \\
\text { reflective acoustic } \\
\text { basement }\end{array}$ & $\begin{array}{c}\text { Mud/ } \\
\text { Muddy-sand }\end{array}$ & $\begin{array}{l}\text { Estuarine } \\
\text { dominance }\end{array}$ & $\begin{array}{l}\text { Predominates } \\
\text { along the } \\
\text { Piraquê- } \\
\text { Mirim; some } \\
\text { and in some } \\
\text { portions of } \\
\text { Piraquê-Açu }\end{array}$ & \\
\hline EC4 & $\begin{array}{c}\text { High signal } \\
\text { penetration, followed } \\
\text { by an acoustic } \\
\text { basement with } \\
\text { irregular/hyperbolic } \\
\text { geometry }\end{array}$ & $\begin{array}{c}\text { Sandy-mud, } \\
\text { associated } \\
\text { with rocky } \\
\text { bottom }\end{array}$ & $\begin{array}{c}\text { No associated } \\
\text { characteristic } \\
\text { process }\end{array}$ & $\begin{array}{l}\text { Portions near } \\
\text { the crystalline } \\
\text { basement }\end{array}$ & \\
\hline
\end{tabular}

\section{CONCLUSIONS}

Four echo-character patterns were identified. The spatial distribution associated with these bottom sediment patterns allowed us to recognize active sedimentary processes in the Piraquê-Acu and Piraquê-Mirim Estuarine System. These processes can be defined as: i) marine processes with transport of sandy sediments by tidal currents that shape the bottom (mouth of the system up to the confluence of both rivers); ii) estuarine processes with input, deposition and resuspension of fine sediments characterized by sandy-mud deposits with high signal penetration, typical of the system inner region; and, iii) erosion or scour lags estuarine processes, with relict sediments exposure. Fluvial processes were only observed in the sediment distribution since no subbottom survey was performed in these areas.

The variation in the penetration degree of the acoustic signal depended on the bottom sediment of the estuary. Higher penetration was observed in areas with finer materials. However, the penetration of the signal as well as aspects of echo-characters (penetration and geometry of reflectors) depended on the morphology/geology of the estuary, which showed rocky outcrops and deposits limited by the tertiary sediments of the Barreiras Formation sometimes present in direct contact with the estuarine waters. In the Piraquê-Acu River, the signal penetration was limited by other physical characteristics of the sediment, possibly density.

\section{ACKNOWLEDGEMENTS}

The authors are thankful to CNPq for financing the Project Casadinho "Geochemical, sedimentary processes and modeling in estuaries with multiple uses of its surroundings" (an association between the graduate programs of Environmental Oceanography/UFES and Geochemistry/UFF). This work is part of Project Casadinho. Thanks are also due to ANP for granting a scholarship for the master degree of the first author, undergraduate scholarship of the third author and to CAPES for the doctoral scholarship of the second author. 


\section{REFERENCES}

BELO WC, DIAS GTM \& DIAS MS. 2002. 0 fundo marinho da baía da Ilha Grande, RJ: o relevo submarino e a sedimentação no canal central. Brazilian Journal of Geophysics, 20(1): 5-15.

CATANZARO LF, BAPTISTA NETO JA, GUIMARÃES MSD \& SILVA CG. 2004. Distinctive sedimentary processes in Guanabara Bay - SE/Brazil, based on the analysis of echo-character $(7.0 \mathrm{kHz})$. Brazilian Journal of Geophysics, 22(1): 69-83.

COOKE CV, MADUREIRA LSP, GRIEP GH \& PINHO MP. 2007. Análise de dados de ecossondagem de fundo oriundos de cruzeiros realizados entre Fortaleza (CE) e Chuí (RS) com enfoque na morfologia e tipos de fundo. Brazilian Journal of Geophysics, 25(4): 443-457.

DALRYMPLE RW, ZAITLIN BA \& BOYD R. 1992. Estuarine Facies Models: conceptual basis and stratigraphic implications. J. Sediment. Petrol., 62(6): $1130-1146$.

DAMUTH JE. 1975. Echo character of the western equatorial Atlantic floor and its relationship to the dispersal and distribution of terrigenous sediments. Marine Geology, 18: 17-45.

FL00D RD. 1980. Deep sea sedimentary morphology: modeling and interpretation of echo-soundings profiles. Marine Geology, 38: 77-92.

FRANCO T, SILVA AE, NASCIMENTO KA, BASTOS AC \& QUARESMA VS. 2011. Morfologia de fundo da desembocadura do Estuário do Piraquê-Açu e da plataforma continental interna adjacente - Aracruz-ES. In: International Congress of the Brazilian Geophysical Society \& EXPOGEF, 12., 2011, Rio de Janeiro. Proceedings... Rio de Janeiro: SBGf, 2011. CD-ROM.

GARCÍA-GARCÍA A, GARCÍA-GIL S \& VILAS F. 2004. Echo Characters and recent sedimentary processes as indicated by high-resolution subbottom profiling in Ría de Vigo (NW Spain). Geo-Mar. Lett., 24: 32-45.

GARCÍA-GIL S, GARCÍA-GARCÍA A \& VILAS F. 1999. Identificación sísmico-acústica de las diferentes formas de aparición de gas en la Ría de Vigo (N0 de España). Rev. Soc. Geol. España, 12(2): 301-307.

LAINE EP, DAMUTH JE \& JACOBI R. 1986. Surficial sedimentary processes revealed by echo-character mapping in the western North Atlantic Ocean. In: VOGT PR \& TUCHOLKE BE (Eds.). The Geology of North America, Vol. M, The Western North Atlantic Region. Geological Soc. America: 427-450.

LEITE TA, BERTOLDIL \& BARROSO GF. 2011. Distribuição da salinidade no sistema estuarino Piraquê-Açu Piraquê-Mirim, Aracruz/ES. In: Congresso Latino-Americano de Ciências do Mar, 14., 2011, Santa Catarina. Proceedings... Santa Catarina: COLACMAR, 2011. CD-ROM.

MARTIN L, SUGUIO K, JEAN-MARIE F \& ARCHANJO JD. 1996. Coastal Quaternary Formations of the Southern Part of the State of Espírito Santo (Brazil). Anais Academia Brasileira de Ciências, 68(3): 381-404.
MELADO ASSG. 2011. Hidrodinâmica e transporte de material particulado em suspensão na desembocadura do Sistema Estuarino PiraquêAçu e Piraquê-Mirim, Aracruz - ES. Master dissertation on Environmental Oceanography, Post-graduate Program on Environmental Oceanography, Centro de Ciências Humanas e Naturais, Universidade Federal do Espírito Santo, 2011.67 pp.

NEVES RC. 2010. Hidrodinâmica e transporte de material particulado em suspensão nos dois braços do Sistema Estuarino Piraquê-Açu e PiraquêMirim, Aracruz - ES. Final Graduation Paper on Oceanography, Centro de Ciências Humanas e Naturais, Universidade Federal do Espírito Santo. $108 \mathrm{pp}$.

NITSCHE FO, BELL R, CARBOTTE SM, RYAN WBF \& FLOOD R. 2004. Process-related classification of acoustic data from the Hudson River Estuary. Marine Geology, 209: 131-145.

PALOMINO D, VAZQUEZ JT, DEL RÍO VD \& FERNÁNDEZ-SALAS LM. 2009. Estudio de los procesos sedimentários recientes de la Bahía de Palma a partir del análisis de la morfología y la respuesta acústica (Islas Baleares, Mediterráneo Occidental). Rev. Soc. Geol. España, 22(1-2): 79-93.

QUARESMAVS, DIAS GTM \& BAPTISTANETO JA. 2001. Caracterização da ocorrência de padrões de sonar de varredura lateral e sísmica de alta frequência (3,5 e 7,0 kHz) na porção sul da Baía de Guanabara - RJ. Brazilian Journal of Geophysics, 18(2): 201-214.

SILVA AE, QUARESMA VS \& BASTOS AC. 2013. Sedimentological sectorization of an Estuarine system in a regressive coast, southeast Brazil. Journal of Sedimentary Research, 83: 994-1003.

SOUZA LAP. 2006. Revisão crítica da aplicabilidade dos métodos geofísicos na investigação de áreas submersas rasas. Doctorate thesis on Chemical and Geological Oceanography, Post-graduate Program on Chemical and Geological Oceanography, Instituto Oceanográfico, Universidade de São Paulo. 284 pp.

VERONEZ JÚNIOR P, BASTOS AC \& QUARESMA VS. 2009a. Morfologia e distribuição sedimentar em um sistema estuarino tropical: Baía de Vitória, ES. Brazilian Journal of Geophysics, 27(4): 609-624.

VERONEZ JÚNIOR P, BASTOS AC, PIZZIN BF, GAVA RD, QUARESMA VS \& SILVA CG. 2009b. Sonar de Varredura Lateral e Sísmica de Alta Resolução Aplicados no Estudo de Ecofácies na Baía de Vitória-ES. Brazilian Journal of Geophysics, 27(3): 411-425.

VIEIRA CV, HORN FILHO NO, BONETTI CVDHC \& BONETTI J. 2008. Caracterização Morfosedimentar e setorização do complexo estuarino da Baía de Babitonga/SC. Boletim Paranaense de Geociências, 62-63: 85106. 


\section{NOTES ABOUT THE AUTHORS}

Alex Evaristo da Silva. Graduated in Oceanography and obtained M.Sc. in Environmental Oceanography at the Universidade Federal do Espírito Santo (2012). Currently is a Ph.D. student in Environmental Oceanography at the Universidade Federal do Espirito Santo. Works in the Geological Oceanography field, with emphasis on Geophysics and Marine Sedimentation.

Pedro Smith Menandro. Graduated in Oceanography and obtained M.Sc. in Environmental Oceanography at the Universidade Federal do Espírito Santo (2014). Currently, is a Ph.D. student in Environmental Oceanography at the Universidade Federal do Espírito Santo. Works in the Geological Oceanography field, with emphasis on Geoacoustics and applied high-resolution geophysics.

Kleverson Alencastre do Nascimento. Graduated in Geography from the Universidade Federal do Espírito Santo (2001) and obtained his Masters in Geology and Geophysics from the Universidade Federal Fluminense (2005).

Valéria da Silva Quaresma. Graduated in Geography from the Universidade Federal Fluminense (1992), obtained M.Sc. in Marine Geology and Geophysics from the Laboratory of Marine Geology of the UFF (1997), and holds a Ph.D. in Geological Oceanography from the University of Southampton (2004). Since 2006 works as a Professor at the Universidade Federal do Espírito Santo as part of the faculty of the Post-graduate Program on Environmental Oceanography (UFES). Works in the field of sediment dynamics and applied high-resolution geophysics.

Alex Cardoso Bastos. Holds a Geology degree from the Universidade Federal do Rio de Janeiro (1993), M.Sc. in Marine Geology and Geophysics from the Universidade Federal Fluminense (1997) and Ph.D. in Sedimentary Dynamics, University of Southampton (2002). Currently, works as an Associate Professor at the Universidade Federal do Espírito Santo and was granted a productivity scholarship from CNPq level II. Is a faculty member of the Post-graduate Program on Environmental Oceanography (UFES). Works in Geological Oceanography with emphasis on Geophysics and Marine Sedimentation. 